\title{
Strategi Pembelajaran PAI \\ Pada Peserta Didik Tuna Grahita Sekolah Dasar Kelas Awal Di Sekolah Dasar Luar Biasa (SDLB) Pembina Tingkat I Cilandak Lebak- Bulus Jakarta Selatan
}

\author{
Siti Khosiah Rochmah \\ Universitas Sultan Ageng Tirtayasa, Serang Banten \\ skhosiah@yahoo.co.id
}

\section{Rika Sa'diyah}

Universitas Muhammadiyah Jakarta, Cirendeu Jakarta Selatan ikafina@gmail.com

\begin{abstract}
This study aims to find out the learning strategy of PAI in children of Primary Grade Students in SDLB Pembina Level I Cilandak South Jakarta in academic year 2014/2015. The subjects of the study were the students of primary school grade tunagrahita with mild (C) and moderate (C1) tunag category of 42 children. Data collection techniques used in the form of observation, interview and documentation study. Processing and data analysis include reduction, data display, conclusion and verification. Procedure is done by conducting reduction, then hold display of data obtained from field and after conducting processing and observation of result of research, then do conclusion and end with verification to get validity final conclusion.

The results showed that PAI learning strategy that includes planning, implementation and evaluation of learning has been done quite well. Learning Planning (curriculum) PAI refers to the general elementary curriculum and has not been modified, substituted or omitted. New curriculum modifications are made on teacher initiative and creativity. Implementation of learning related to objectives, materials, methods, media, and assessment needs to be tailored to the needs and abilities of each child individually because the ability of learners can not be equalized and standardized. Evaluation of learning outcomes both related to the procedures, mechanisms, means and tools used the same as those done in public elementary schools. But there has been a modification on the form of questions, not applied the national exam (UN) but the school exam for final evaluation of the program.
\end{abstract}

Keywords: Students, children of Primary Grade, the learning strategy 


\begin{abstract}
Abstrak: Penelitian ini bertujuan untuk mengetahui strategi pembelajaran PAI pada anak tuna grahita SD Kelas Awal di SDLB Pembina Tingkat I Cilandak Jakarta Selatan pada tahun pelajaran 2014/2015. Subyek penelitian adalah peserta didik tunagrahita SD Kelas Awal dengan kategori tunag rahita ringan (C) dan sedang (C1) yang berjumlah 42 anak. Teknik pengumpulan data yang digunakan berupa observasi, wawancara dan studi dokumentasi.

Pengolahan dan analisis data meliputi reduksi, display data, mengambil kesimpulan dan verifikasi. Prosedur dilakukan dengan mengadakan reduksi, selanjutnya mengadakan display data yang didapat dari lapangan dan setelah mengadakan pengolahan dan pengamatan atas hasil dari penelitian, selanjutnya dilakukan penyimpulan dan diakhiri dengan verifikasi untuk mendapat validitas kesimpulan akhir.

Hasil penelitian menunjukkan bahwa: strategi pembelajaran PAI yang meliputi perencanaan, pelaksanaan dan evaluasi pembelajaran telah terlaksana dengan cukup baik. Perencanaan pembelajaran (kurikulum) PAI mengacu kepada kurikulum SD umum dan belum dilakukan modifikasi, substitusi, ataupun omisi. Modifikasi kurikulum baru dilakukan atas inisiatif dan kreativitas guru. Pelaksanaan pembelajaran yang terkait dengan tujuan, materi, metode, media, dan asesmen perlu disesuaikan dengan kebutuhan dan kemampuan masingmasing anak secara individual karena kemampuan peserta didik tidak dapat dipersamakan dan distandarisasikan. Evaluasi hasil pembelajaran baik yang terkait dengan prosedur, mekanisme, cara dan alat yang digunakan sama seperti yang dilakukan pada SD umum. Namun telah terjadi modifikasi pada bentuk soal, tidak diberlakukan ujian nasional (UN) melainkan ujian sekolah untuk evaluasi akhir program.
\end{abstract}

Kata Kunci: Peserta Didik Tuna Grabita, Strategi Pembelajaran

\title{
Pendahuluan
}

Peserta didik tunagrahita merupakan anak yang mengalami kelainan kecerdasan dengan empat kategori, yaitu tunagrahita ringan (C) dengan IQ 7055, sedang (C1) dengan IQ 55-40, berat (C2) dengan IQ 40-25 dan berat sekali dengan $\mathrm{IQ}<25$. Peserta didik tuna grahita atau yang dikenal dengan istilah tuna mental, cacat mental atau retalisasi mental mempunyai kecerdasan di bawah kecerdasan peserta didik normal, yang tidak memungkinkan untuk mengikuti pelajaran atau pendidikan di sekolah umum karena intelegensi di bawah rata-rata peserta didik normal, sehingga perkembangan berfikirnya sangat lamban. Kemampuan peserta didik tunagrahita maksimal ekuivalen dengan kemampuan 
akademik peserta didik kelas III SD umum. Sedangkan secara fisik, peserta didik tuna grahita memiliki ciri-ciri, di antaranya: penampilan fisik tidak seimbang, misalnya kepala terlalu kecil/besar, tidak dapat mengurus diri sendiri sesuai usia, tidak ada/kurang sekali perhatiannya terhadap lingkungan, dan koordinasi gerakan kurang (gerakan sering tidak terkendali).

Dalam menghadapi kondisi peserta didik seperti ini, guru agama Islam tentunya dituntut untuk mampu memilih dan memilah strategi pembelajaran alternatif yang dapat diterapkan dalam pembelajaran PAI secara efektif dan efesien. Penentuan strategi penting dilakukan sebab strategi mengandung beberapa komponen pembelajaran, baik dari perencanaan, pelaksanaan hingga evaluasi. Dengan demikian, penentuan strategi pembelajaran dari awal dapat menjadi rambu-rambu bagi guru agar tujuan yang diharapkan tercapai, meskipun dalam pelaksanaannya seringkali tidak sesuai perencanaan.

Strategi pembelajaran di SDLB tentu berbeda dengan di SD umum, oleh karena itu strategi sebagai bagian dari upaya untuk mencapai suatu tujuan pembelajaran penting dilakukan oleh guru. Selain dituntut untuk mampu memilih dan menggunakan berbagai strategi, guru juga perlu memiliki kemampuan memilih dan menggabungkan strategi yang satu dengan strategi pembelajaran lainnya, terlebih jika peserta didiknya berkebutuhan khusus. Hal tersebut tentu akan menimbulkan pertanyaan bagi guru bahwa strategi alternatif seperti apakah yang tepat untuk diterapkan pada peserta didik ini khususnya dalam pembelajaran PAI agar dapat diimplementasikan dalam kehidupan seharihari. Suatu pembelajaran tentu akan terlaksana dengan baik jika menggunakan strategi pembelajaran yang sesuai dengan karakteristik belajar dan kebutuhan peserta didik. Dengan demikian, dalam memilih strategi pembelajaran, guru harus mempertimbangkan dengan hati-hati faktor tingkat perkembangan dan cara belajar, kebutuhan dan minat peserta didik, karena strategi pembelajaran yang akan digunakan harus dapat memfasilitasi belajar peserta didik

Strategi pembelajaran PAI di Sekolah Luar Biasa hendaknya dilakukan oleh guru agama Islam yang luar biasa, sebab secara empiris Lembaga Pendidik dan Tenaga Kependidikan (LPTK) yang menghasilkan calon guru agama Islam seperti Fakultas Tarbiyah tidak dibekali dengan berbagai keahlian khusus untuk mengajar di Sekolah Luar Biasa dan kurikulumnya pun belum mengakomodir kebutuhan peserta didik yang berkebutuhan khusus.

Guru agama Islam Islam harus lebih mengutamakan proses belajar dalam perspektif "menjadi" di atas perspektif "memiliki”. Dengan demikian, 
setiap proses pembelajaran adalah assimilasi pembelajaran (miximizing "student learning”), dan jika perlu mengurangi porsi ceramah (miximizing "teacher teaching") dengan mengaktifkan peserta didik untuk mencari dan menemukan serta aktifitas belajar sendiri, sehingga konsep metodologi pembelajaran yang terbangun adalah "pembelajaran" (learning) bukan "pengajaran" (teaching) ${ }^{1}$. Inilah tantangan yang dihadapi guru agama Islam untuk mengemas dan mengimplementasikan materi-materi pelajaran Agama Islam yang tertuang dalam kurikulum kepada peserta didik.

Materi Agama Islam yang menyangkut ajaran keimanan, seperti iman kepada Allah atau hari kiamat, dan ibadah praktis, seperti sholat, puasa dan hajiumrah merupakan materi pelajaran yang membutuhkan strategi khusus terutama bagi peserta didik berkebutuhan khusus. Sementara pembelajaran yang berkualitas akan tercapai jika guru melibatkan seluruh indera peserta didik secara optimal, seperti melihat, mendengar, menyentuh, merasa dan mencium. ${ }^{2}$ Mengatakan bahwa seorang peserta didik dianggap berkelainan dalam hal ini kecacatan mental, apabila memerlukan persyaratan pendidikan yang berbeda dari rata - rata peserta didik normal dimana IQ-nya dibawah rata-rata dari peserta didik normal tersebut, maka mereka membutuhkan belajar secara efektif melalui program, pelayanan, fasilitas, dan materi khusus.

\section{Strategi Pembelajaran}

Strategi dalam Kamus Ilmiah Populer memiliki makna siasat, yaitu siasat untuk mendapatkan sesuatu. Strategi dalam pengertian sempit diartikan sebagai seni menggunakan kekuatan militer untuk mencapai tuuan-tujuan yang telah ditetapkan. Sedangkan strategi dalam arti luas diartikan sebagai seni (art) semua kekuatan.

"Mengelola pembelajaran" atau "mengajar" menurut pandangan para ahli diartikan sebagai berikut 1) Tyson dan Caroll mengartikan mengelola pembelajaran adalah " a way working with student, a process of interaction, the teacher does something to student; the students do something in return" (sebuah cara dan proses hubungan timbal balik antara guru dan peserta didik yang sama-sama aktif melakukan kegiatan). 2) Tardif menyederhanakan pengertian mengelola

${ }^{1}$ Mohammad Ansyar, Kurikulum dalam Menyongsong Otonomi Pendidikan di Era Globalisasi, Peluang, Tantangan, dan Arah, dalam jurnal Pendidikan Islam TA’DIB, Maret 2002, (No. 04):109

${ }^{2}$ M. Gagne, Robert, Essentials of Lerning for Instruction, Florida, Deiden Press, 1975: 19 
pembelajaran yakni "any action performed by an individual (the teacher) with the intention of facilitating learning in another individual (the learner)". Pengertian ini menunjukkan bahwa mengelola pembelajaran (mengajar) adalah perbuatan yang dilakukan oleh seorang (guru) dengan tujuan membantu atau memudahkan orang lain (peserta didik) melakukan kegiatan belajar. 3) mengartikan mengajar sebagai bentuk pembelajaran (instruction) ${ }^{3}$. Dalam mengelola pembelajaran (mengajar) seorang guru menentukan model pengajaran dan metode serta media yang digunakan ${ }^{4}$. Secara sekilas menyatakan bahwa mengelola pembelajaran adalah usaha untuk menciptakan kondisi sedemikan rupa sehingga terjadi interaksi antara murid dan lingkungannya termasuk guru, alat pelajaran dan lain sebagainya dalam rangka pencapaian tujuan yang ditentukan. 4) mengelola pembelajaran (mengajar) adalah suatu profesi di mana seseorang menggunakannya sebagai tanggungjawab dari suatu pengalaman "ahli". Menurutnya mengelola pembelajaran adalah suatu seni yang menuntut visi, intuisi, bakat, komitmen dan kreativitas yang senyatanya dimiliki ketika mengelola pembelajaran (mengajar) tersebut. Mengelola pembelajaran (mengajar) juga merupakan ilmu, karena menuntut adanya pengetahuan dan keterampilan yang dapat dipelajari. ${ }^{5}$ 5) mengelola pembelajaran (mengajar) adalah merubah perilaku, yaitu membantu peserta didik untuk belajar, atau belajar lebih cepat, atau belajar lebih efisien dibanding mereka belajar sendiri. ${ }^{6}$ Dalam konsep lama, mengajar adalah proses memberikan/ menyampaikan pengetahuan dan keterampilan yang diperlukan kepada peserta didik. Konsep sekarang mengajar atau mengelola pembelajaran adalah memberikan pemahaman dan memandu peserta didik baik individu maupun kelompok, ini juga berarti mengajar atau mengelola pembelajaran adalah memfasilitasi peserta didik untuk mendapatkan pengalaman dan untuk tumbuh secara terus menerus menjadi orang dewasa.

Selanjutnya, beberapa tokoh berpendapat tentang strategi pembelajaran yang diantaranya dimaknai sebagai berikut: 1) strategi pembelajaran merupakan cara-cara yang dipilih untuk menyampaikan metode pembelajaran dalam lingkungan pembelajaran tertentu. Mengingat bahwa setiap tujuan dan metode

3 Muhibbin Syah, Psikologi Pendidikan dengan Pendekatan Baru, Bandung, Remaja Rosdakarya, 2008: 182

${ }^{4}$ Ibid, 149

${ }^{5}$ E Woolfolk, Anita. Educational Psycho and the Classroom Teacher. Boston, Allyn and Bacon. 1993:4

6 S. Vargas, Julie. Behavioral Psychology for Teachers. New York, Harper and Row Publishers. 1997:6 
pembelajaran berbeda satu dengan yang lainnya, maka jenis kegiatan belajar yang harus dipraktekkan oleh peserta didik membutuhkan persyaratan yang berbeda pula. 2) strategi pembelajaran adalah gambaran komponen materi dan prosedur atau cara yang digunakan untuk memudahkan peserta didik belajar. 3) strategi pembelajaran adalah keseluruhan prosedur yang sistematis untuk mencapai tujuan pembelajaran ${ }^{7}$. 4) strategi pembelajaran dapat diartikan sebagai setiap kegiatan yang dipilih, yaitu yang dapat memberikan fasilitas atau bantuan kepada peserta didik menuju tercapainya tujuan pembelajaran tertentu.

Dengan demikian, strategi pembelajaran harus mengandung penjelasan tentang metode/prosedur dan teknik yang digunakan selama proses pembelajaran berlangsung. Dengan perkataan lain, strategi pembelajaran mengandung arti yang lebih luas dari metode dan teknik. Artinya, metode/prosedur dan teknik pembelajaran merupakan bagian dari strategi pembelajaran. Strategi pembelajaran adalah cara-cara yang akan digunakan oleh pengajar untuk memilih kegiatan belajar yang akan digunakan selama proses pembelajaran. Pemilihan tersebut dilakukan dengan mempertimbangkan situasi dan kondisi, sumber belajar, kebutuhan dan karakteristik peserta didik yang dihadapi dalam rangka mencapai tujuan pembelajaran tertentu.

Dari berbagai pendapat dapat disimpulkan bahwa strategi pembelajaran adalah suatu rencana kegiatan pembelajaran yang harus dikerjakan oleh guru dan peserta didik agar tujuan pembelajaran dapat dicapai secara efektif dan efisien. Sedangkan pengimplementasiannya menggunakan berbagai metode, teknik dan taktik yang sifatnya praktis. Dengan demikian strategi pembelajaran sifatnya masih konseptual.

\section{Pendidikan Agama Islam (PAI)}

Pengertian Pendidikan Agama Islam sebagaimana dirumuskan oleh Puskur adalah upaya sadar dan terencana dalam menyiapkan peserta didik untuk mengenal, memahami, menghayati hingga mengimani, bertaqwa, dan berakhlak mulia dalam mengamalkan ajaran agama Islam dari sumber utamanya kitab suci Al Quran dan Hadits, melalui kegiatan bimbingan, pengajaran, latihan, serta penggunaan pengalaman. Pendidikan Agama Islam merupakan bimbingan atau pimpinan secara sadar oleh pendidik yang bersumberkan pada nilai-nilai agama

${ }^{7}$ Boric, Gary, D. Effective Teaching Methode. Thir Edition. Ohio, Merill an Imprint of Prentice Halll, 1996 :11 
Islam, disamping menampakkan atau membentuk tingkah laku yang dijiwai dengan nilai-nilai agama, juga mengembangkan ilmu pengetahuan yang sejalan dengan nilai Islam ${ }^{8}$. Pendidikan Agama Islam adalah usaha sadar yang dapat dilakukan seseorang atau lembaga pendidikan secara sadar untuk mengembangkan potensi peserta didik, baik yang bersifat jasmani maupun rohani berdasarkan ajaran Islam? .

Tujuan pendidikan Agama Islam adalah untuk menumbuhkan dan meningkatkan keimanan, melalui pemberian dan pemupukan pengetahuan, penghayatan, pengamalan serta pengalaman peserta didik tentang agama Islam, sehingga menjadi manusia muslim yang terus berkembang dalam hal keimanan, ketaqwaannya kepada Allah SWT. serta berakhlak mulia dalam kehidupan pribadi, bermasyarakat, berbangsa dan bernegara, serta untuk dapat melanjutkan pada jenjang pendidikan yang lebih tinggi.

Pendidikan Agama Islam berfungsi untuk: 1) penanaman nilai ajaran Islam, 2) pengembangan keimanan dan ketakwaan kepada Allah SWT serta akhlak mulia, 3) penyesuaian mental peserta didik terhadap lingkungan, 4) pengamalan ajaran agama Islam dalam kehidupan sehari-hari, 5) pencegahan peserta didik dari hal-hal negatif budaya asing yang akan dihadapinya sehari-hari, 6) pengajaran tentang ilmu pengetahuan keagamaan secara umum sistem dan fungsionalnya, 6) penyaluran peserta didik untuk mendalami pendidikan agama ke lembaga pendidikan yang lebih tinggi.

Materi Pendidikan Agama Islam secara keseluruhan terbagi dalam empat cakupan: Al Quran dan Hadits, Aqidah, Akhlak, dan Fiqh. Empat aspek materi Pendidikan Agama Islam di atas menekankan adanya keseimbangan, keselarasan dan keserasian antara hubungan manusia dengan Allah SWT, hubungan manusia dengan diri sendiri dan hubungan manusia dengan alam sekitar.

\section{Tuna Grahita}

Tuna grahita merupakan istilah baru yang sebelumnya dikenal dengan istilah tuna mental, cacat mental atau retalisasi mental. Dari berbagai istilah yang berkembang, istilah di atas memiliki pengertian yang sama, yaitu anak yang mengalami hambatan dalam perkembangan mental. Anak tunagrahita adalah anak yang mempunyai kecerdasan di bawah kecerdasan anak normal, yang tidak

\footnotetext{
${ }^{8}$ Arifin, Metodik Khusus Pendidikan Agama, Jakarta, Hidakarya, 2001: 13

9 Zuhairini dkk, Metodologi Pengajaran Agama Islam, Jakarta, Pustaka Firdaus, 2004: 27
} 
memungkinkan untuk mengikuti pelajaran atau pendidikan di sekolah umum karena intelegensi di bawah rata-rata anak normal, sehingga perkembangan berfikirya sangat lamban ${ }^{10}$.

Ketunagrahitaan mengacu pada intelektual umum yang secara signifikan berada di bawah rata-rata. Peserta didik tunagrahita mengalami hambatan dalam tingkah laku dan penyesuaian diri. Semua itu berlangsung atau terjadi pada masa perkembangannya. Seseorang dikatakan tunagrahita apabila memiliki tiga indikator, yaitu: 1) keterhambatan fungsi kecerdasan secara umum atau di bawah rata-rata, 2) ketidakmampuan dalam prilaku sosial/adaptif, dan 3) hambatan perilaku sosial/adaptif terjadi pada usia perkembangan yaitu sampai dengan usia 18 tahun.

\section{Sekolah Luar Biasa}

SLB merupakan lembaga pendidikan khusus yang menangani pendidikan untuk peserta didik yang memiliki ketidaksempurnaan fisik atau salah satu dari organ tubuhnya tidak berfungsi. Adapun batasan - batasan bahwa anak tergolong luar biasa atau cacat mental berkelainan adalah anak yang menyimpang dari rata - rata anak normal dimana mereka memiliki masalah pada mental, kemampuan - kemampuan sensorik, fisik dan neuromuskular, perilaku sosial dan emosional, maupun kemampuan berkomunikasi.

Penelitian sejenis tentang strategi pembelajaran Pendidikan Agama Islam di Sekolah Luar Biasa (SLB) pernah dilakukan diantaranya oleh Muhammad Khoddik mahasiswa Fakultas Tarbiyah UIN Sunan Kalijaga Yogyakarta dengan topik kajian "Strategi Pembelajaran Pendidikan Agama Islam bagi Peserta Didik SMPLB Tuna Rungu di SLB Yapenas Condong Catur Depok Sleman Yogyakarta" Dari hasil penelitian diperoleh data bahwa strategi pembelajaran yang dipakai dalam pembelajaran Pendidikan Agama Islam bagi peserta didik tuna rungu adalah ceramah, keteladanan, tanya jawab, pemberian tugas, dan drill atau latihan. Pendekatan yang dipakai adalah pendekatan individual, kelompok, dan pembiasaan. Dalam mendukung terlaksananya strategi dengan baik bagi peserta didik tunarungu, guru menggunakan pendekatan berbahasa dengan Metode Maternal Reflektif (MMR) yaitu metode pembelajaran yang memuat percakapan dari hati ke hati, percakapan linguistik, dan membiasakan peserta didik untuk

${ }^{10}$ Depdiknas, Pedoman Khusus Penyelenggaraan Pendidikan Inklusif: Pedoman Khusus Kegiatan Pembelajaran, Jakarta, Depiknas, 2006: 18 
menyimak, berbicara, membaca dan menulis sesuai kemampuan peserta didik dengan dibina oleh guru.

Desi Iriyani dalam penelitiannya tentang "Metode Pembelajaran Pendidikan Agama Islam pada Anak Tuna grabita di SLB B-C di YPAALB Langenharjo Sukoharjo" Hasil penelitian menyatakan bahwa guru SLB B/C YPAALB Langenharjo dalam menyampaikan materi kepada peserta didik menggunakan beberapa metode pembelajaran diantaranya meliputi metode ceramah dan hafalan, demonstrasi, apersepsi, menyanyi dan metode latihan. Selain itu, guru dalam menyampaikan materi menggunakan bahasa yang sederhana dan dilakukan secara berulang-ulang.

\section{Metodologi Penelitian}

Penelitian ini mengenai strategi pembelajaran PAI pada peserta didik tunagrahita SD Kelas Awal di SDLB Pembina tingkat I Cilandak Lebak Bulus. Penelitian dilakukan pada peserta didik tunagrahita SD Kelas Awal dengan kategori tunagrahita ringan (C) dan Sedang (C1) dengan menggunakan pendekatan studi kualitatif naturalistik. Penelitian melibatkan seluruh anak tunagrahita SDLB yang berjumlah 42, terdiri atas laki-laki 28, dan perempuan sebanyak 14 peserta didik. Teknik pengumpulan data yang digunakan berupa observasi, wawancara dan studi dokumentasi.

Pengolahan dan analisis data meliputi reduksi, display data, mengambil kesimpulan dan verifikasi. Prosedur dilakukan dengan mengadakan reduksi, selanjutnya mengadakan display data yang didapat dari lapangan dan setelah mengadakan pengolahan dan pengamatan atas hasil dari penelitian, selanjutnya dilakukan penyimpulan dan diakhiri dengan verifikasi untuk mendapat validitas kesimpulan akhir.

\section{Hasil dan Pembahasan Penelitian}

Hasil penelitian mengenai strategi pembelajaran PAI pada peserta didik tunagrahita SD Kelas Awal dapat dijelaskan sebagaiberikut:

\section{Perencanaan Pembelajaran}

Kurikulum untuk tingkat satuan pendidikan Sekolah Luar Biasa masih sama dengan SD umum khususnya dalam hal Standar Kompetensi Lulusan (SKL) dan Standar Isi (SI). Kurikulum tingkat satuan pendidikan SDLB 
khususnya tunagrahita dalam dokumen KTSP SDLB belum dimodifikasi atau disubsitusi maupun diomisi. Namun, dalam pelaksanaannya atas inisiatif dan kreatifitas guru telah dilakukan modifikasi khususnya mengenai materi dan target-target yang ingin dicapai. Pada dasarnya modifikasi belum dilaksanakan secara kelembagaan, akan tetapi buku panduannya sedang direncanakan.

\section{a. Perencanaan Tahunan}

Perencanaan tahunan adalah perencanaan kegiatan yang akan dilakukan selama satu tahun yang terdiri atas 14 tema, yaitu: 1) Diri sendiri, 2) Keluarga, 3) Lingkungan, 4) Transportasi, 5) Kesehatan, 6) Kebersihan, 7) Keamanan, 8) Hewan, 9) Tumbuhan, 10) Pekerjaan, 11) Gejala alam dan peristiwa, 12) Rekreasi, 13), Negara, 14) Alat Komunikasi.

\section{b. Perencanaan Semesteran}

Perencanaan semesteran merupakan penjabaran dari perencanaan tahunan. Perencanaan semester ini terbagi menjadi dua program semesteran, yaitu semester satu dan semester dua. Dalam satu semester empat tema, yaitu Diri Sendiri, Keluarga, Lingkungan, serta Hewan dan Tumbuhan menjadi topik pembahasan yang masing-masing secara umum memiliki alokasi waktu 20 jam. Tema menjadi suatu pendekatan sebagai sarana untuk membekali program akademis anak, yang terdiri atas beberapa mata pelajaran, yaitu: bahasa Indonesia, Matematika, IPA, IPS, dan Pkn.

\section{c. Perencanaan Bulanan/Mingguan/Harian}

Dari program semesteran kemudian dijabarkan ke dalam Silabus. Silabus yang dibuat oleh setiap guru kelas tidak memasukkan bidang pengembangan Agama. Demikian halnya dalam penyusunan Rencana Pelaksanaan Pembelajaran (RPP).

\section{Pelaksanaan}

Berbagai pemikiran yang perlu diperhatikan dan perlu dijadikan rujukan dalam pelaksanaan pembelajaran PAI bagi anak tunagrahita SD Kelas Awal adalah modifikasi baik terhadap tujuan, isi, proses, dan modifikasi evaluasi, 
fungsional, analisis tugas yang lebih detail, dan pembelajaran dengan memanfaatkan teman sebaya sebagai media.

\section{a. Tujuan}

Tujuan-tujuan yang tertuang dalam kurikulum sebagai rujukan/landasan awal dalam menetapkan tujuan pembelajaran PAI bagi peserta didik tunagrahita SD Kelas Awal adalah: 1) mengembangkan kemampuan untuk melafalkan suratsurat pendek Al-Quran dan doa sehari-hari, 2) mengenal Allah melalui ciptaannya di lingkungan sekitarnya, 3) membiasakan perilaku baik sehari-hari di rumah, sekolah dan masyarakat, 4) menjalankan syariat agama Islam dalam kehidupan sehari-hari sesuai kemampuannya.

\section{b. Materi}

Materi PAI yang dikembangkan sudah dimodifikasi/disederhanakan, konkret, praktis, kontekstual telah diurut dari yang paling mudah hingga yang paling sulit, telah disesuaikan dengan kemampuan masing-masing anak, diajarkan secara bertahap, berkesinambungan, dan berulangkali sehingga menjadi pembiasaan. Adapun ruang lingkup materi PAI pada peserta didik tunagrahita SD Kelas Awal meliputi 4 aspek, yaitu Alqur'an-Hadits, Aqidah, Akhlak dan fiqh. Keempat lingkup materi tersebut dijabarkan ke dalam sub materi.

Modifikasi materi sementara ini dilakukan atas kreativitas guru, karena buku panduan dalam proses penyusunan dan penyelesaian. Sekalipun tarikh tidak termasuk dalam ruang lingkup materi, namun guru menggunakan cerita tokoh-tokoh agama, seperti Umar ibn Khattab, Nabi Ayub, dan lainnya agar sifat-sifatnya dijadikan suri teladan atau dicontoh oleh peserta didik.

\section{c. Metode}

Proses pembelajaran PAI pada peserta didik tunagrahita SD Kelas Awal telah mengikuti beberapa prinsip pembelajaran, diantaranya: 1) pengalaman dan pembiasaan, khususnya dalam hal belajar menjalankan sholat (mengajak anak mengerjakan sholat, mengajak ke mesjid, peralatan sholat, menghadap kiblat, membimbing jumlah rokaat yang benar, melibatkan dalam kegiatan peringatan hari-hari besar agama) wudlu, berperilaku bersih, tertib, menolong orang lain, jujur, membaca doa bersama ketika memulai dan mengakhiri belajar. 2) Kerja 
sama dengan orang tua/keluarga; berbagai program PAI yang diadakan di sekolah telah dikomunikasikan dan dikoordinasikan dengan orang tua/keluarga peserta didik. Kedua belah pihak telah melakukan pembinaan dan pengawasan, sehingga yang diprogramkan di sekolah didukung penuh oleh keluarga. Bentuk kerja sama lain adalah konsultasi dan menerima keluhan orang tua tentang kesulitan belajar dan masalah-masalah lain peserta didik. 3) Pujian; guru seringkali memberikan pujian berupa verbal kepada peserta didik yang berhasil melakukan pekerjaan dengan baik. Sementara metode pembelajaran PAI yang digunakan adalah metode ceramah, tanya jawab, demonstrasi dan pemberian tugas seperti Pekerjaan Rumah, membawa infak mingguan pada tiap hari Jumat berupa beras atau uang.

\section{d. Media}

Media sebagai alat bantu yang digunakan untuk mengefektifkan proses komunikasi agar materi, informasi dan pesan-pesan pembelajaran dapat dilaksanakan secara tepat dan cepat. Beberapa media yang baru digunakan pada peserta didik tuna grahita SD Kelas Awal saat ini adalah media pembelajaran Audio-Visual Aids dalam plash, bentuk gambar diam, seperti poster dan flash card huruf Hijaiyah. Di samping itu juga menggunakan benda-benda asli, seperti sajadah, Al-Quran, mukena, peci dan sarung. Semua kelas pembelajaran PAI dilangsungkan di laboratorium PAI, kecuali peserta didik yang hiperaktif. Media dalam bentuk plash dapat dilihat pada CD khusus.

\section{e. Assesmen}

Untuk mengukur kemampuan, perkembangan, kemajuan belajar dan keberhasilan peserta didik dalam mengikuti proses pembelajaran dilakukan penilaian terhadap aspek afektif, psikomorik dan kognitif. Penilaian diutamakan pada aspek afektif dan psikomotorik. Penilaian dilakukan berdasarkan prinsipprinsip: mengutamakan aspek afektif dan psikomotorik daripada aspek kognitif, memperhatikan jenis, karakteristik dan kemampuan peserta didik secara individual. Penilaian harian atau formatif dilakukan dengan cara lisan dan praktik (perbuatan).

\section{Evaluasi Hasil Pembelajaran}


Evaluasi Pembelajaran adalah kegiatan yang dilakukan untuk untuk memperoleh informasi yang akurat mengenai tingkat penguasaan kompetensi yang telah ditetapkan dan keberhasilan peserta didik. Evaluasi hasil belajar dilakukan dalam bentuk ulangan harian/formatif, Ujian Tengah Semester (UTS), dan Ujian Akhir Semster (UAS). UTS dan UAS dijadwal secara umum dan dilakukan secara klasikal.

Proses UTS dan UAS telah dilakukan modifikasi terhadap isi, alat, tempat, dan cara. Modifikasi tidak dilakukan terhadap waktu, artinya waktu penilaian tidak diperpanjang/sesuai dengan jadwal yang tekah dibuat. Cara penilaian dilakukan secara tertulis tetapi dimodifikasi dngan cara guru membacakan soal peserta didik menuliskan jawaban, soal disesuaikan dengan materi yg diajarkan. Bentuk soal pilihan ganda, isian singkat, dan menirukan atau menulis kata yang disediakan di atasnya. Guru mendampingi cara menirukan atau menuliskan kata secara individual. Soal pilihan ganda untuk Tunagrahita C1 (ringan) disajikan dengan 3 (tiga) opsi pilihan jawaban, sedangkan untuk tunagrahita sedang (C soal pilihan danda disajikan dengan 2 opsi jawaban. Untuk seluruh soal disajikan $60 \%$ gambar, 40\% dalam bentuk verbal.

Tempat penilaian disesuaikan dengan materi yang diujikan. Jika yang dinilai dalam bentuk praktik seperti wudlu atau shalat, maka tempat tes dilakukan di luar kelas, yaitu langsung di tempat wudlu dan mushalla. Sedangkan untuk tes tertulis di dilakukan di kelas. Pelaksanaan tes tertulis dilakukan secara klasikal, sedangkan untuk praktik dilakukan secara individual. Evaluasi hasil belajar untuk peserta didik tunagrahita tidak menggunakan alat khusus seperti tuna rungu atau tunanetra.

Sistem pelaporan dalam Buku Laporan Pendidikan disajikan dalam bentuk skor/nilai angka dan huruf dari 8 mata pelajaran, muatan lokal, program khusus Bina Diri, Pengembangan Diri (kepribadin, ekstra kurikuler, pembiasaan yang meliputi kedisiplinan dan tanggung jawab, kebersihan, kerja sama, kesopanan, kemandirian, kerajinan, kejujuran, kepemimpinan, ketaatan, dan kegiatan sehari-hari. Semua aspek yang dinilai selain dalam bentuk skor tersebut juga dideskripsikan secara detail.

Standar kelulusan tergantung kepada kemampuan masing-masing peserta didik, sistem kenaikan kelas otomatis, dan penilaian pada ijazah tunagrahita (C, C1), Tunadaksa sedang (D1), Tunaganda (G) didasarkan pada Ujian Sekolah (US), tidak ada Ujian Nasional (UN). Berbeda dengan SLB A, B, D, dan E, untuk SLB kelompok ini didasarkan pada nilai UN dan US. 
Lebih lanjut, pembahasan hasil penelitian dapat dianalisa sebagai berikut:

\section{Perencanaan}

Kurikulum SDLB masih mengacu kepada kurikulum SD umum, termasuk Standar Kompetensi Lulusan dan Standar Isi, baik Standar Kompetensi maupun Kompetensi Dasar. Namun demikian, kurikulum telah dijabarkan ke dalam alur yang benar. Program Tahunan Semesteran, Silabus dan RPP juga telah dirancang guru secara ideal. Dalam pelaksanaannya, guru masih dapat menurunkan standar untuk menyesuaikan dengan kebutuhan masingmasing peserta didik.

Hakikatnya perencanaan pembelajaran di SDLB telah memenuhi syarat dan disusun guru sesuai kriteria. Hanya saja penggunaan istilah mata pelajaran dalam acuan RPP sebaiknya diperbaiki dengan menggunakan istilah tema. Hal ini untuk menghindari adanya pemahaman yang mengisyaratkan antara aspek kemampuan yang akan dikembangkan tidak terintegrasi dengan tema yang dibahas. Sementara untuk memenuhi kebutuhan masing-masing individu, guru hendaknya merencanakan berbagai komponen pembelajaran ke dalam RPP, meskipun dalam praktiknya sangat situasional. Pandangan guru agama Islam dan guru kelas SDLB tunagrahita tentang perencanaan pembelajaran sebatas untuk memenuhi tuntutan administrasi tampak pada saat guru akan memulai pelajaran. Kondisi kelas dan benda yang dibawa anak ke sekolah menjadi tema/topik pembahasan sebagaimana pernyataan salah seorang guru agama Islam yang mengungkapkan bahwa perencanaan yang dibuat seideal apapun pelaksanaannya akan sangat tergantung pada situasi dan kebutuhan masing-masing anak pada saat itu.

\section{Pelaksanaan}

\section{a. Tujuan}

Tujuan pembelajaran PAI bagi peserta didik tunagrahita SD Kelas Awal secara umum mengacu pada Standar Kompetensi Lulusan, yang dijabarkan ke Standar Kompetensi (SK) dan Kompetensi Dasar (KD) yang tertuang dalam kurikulum. Selanjutnya SK \& KD dijabarkan ke dalam Silabus, baik sebagai Perencanaan Tahunan, Semesteran, Bulanan, Mingguan maupun Harian atau Rencana Pelaksanaan Pembelajaran (RPP). Namun, SK \& KD yang ada bukan 
keharusan yang mutlak, karena kemampuan peserta didik tidak dapat dipersamakan dan distandarisasikan.

\section{b. Materi}

Materi Pendidikan Agama Islam pada prinsipnya harus mampu mengantarkan peserta didik untuk mengembangkan suatu pola hidup yang seimbang dan selaras. Keseimbangan antara hubungan manusia dengan Allah SWT, hubungan manusia dengan sesama manusia, hubungan manusia dengan diri sendiri, serta hubungan manusia dengan alam sekitarnya.

Secara operasional, mata pelajaran PAI yang diselenggarakan di sekolah, mengacu pada Standar Kompetensi (SK) dan Kompetensi Dasar (KD) yang telah ditetapkan dalam kurikulum nasional. SK dan KD pada hakikatnya adalah standar minimal materi yang harus disampaikan dan dikuasai oleh peserta didik. Oleh karena itu, untuk memahami materi lebih lanjut, guru seyogyanya melakukan pencermatan dan analisis terhadap SK dan KD yang ada dalam kurikulum karena SK dan KD bukan suatu keharusan yang wajib diajarkan dan disampaikan langsung kepada peserta didik. SK dan KD sebagai landasan/titik awal bagi guru untuk menganalisis dan mengembangkan materi yang tepat bagi peserta didik tunagrahita.

Guru agama Islam hendaknya dapat merubah atau menyesuaikan materi PAI dengan kemampuan, kesiapan dan kondisi peserta didik. Menurut pandangan hukum Islam, manusia yang kemampuannya terbatas (tidak normal), maka ta'lif hukum syar'inya (beban) hukum Islam berbeda dengan manusia yang memiliki kemampuan yang normal. Sementara peserta didik tunagrahita merupakan anak yang memiliki kekurangan atau kelemahan akal (mental intelegensi), maka ta'lif hukumnya tidak bisa disamakan dengan anak/orang-orang yang sempurna akal pikirnya serta jasmani dan rohaninya.

Pengembangan materi PAI telah dilakukan oleh guru agama Islam sesuai dengan prinsip-prinsip yang dianjurkan, bahkan telah dilakukan pengembangan materi dan penyampaiannya berulang-ulang.

\section{c. Metode}

Pelaksanaan pembelajaran pada prinsipnya dilakukan dalam tiga tahap, yaitu pembukaan, kegiatan inti dan penutup. Dalam kegiatan pembukaan dilakukan dengan mengacu pada RPP yang telah dibuat, akan tetapi dalam 
prakteknya belum sesuai dengan acuan tersebut, seperti dalam hal menciptakan suasana pembelajaran yang aktif, interaktif, kreatif, efektif, dan menyenangkan. Sebelum kegiatan pembelajaran berlangsung, guru biasanya akan mengkondisikan peserta didik agar dapat mengikuti materi yang akan dibahas. Pengkondisian peserta didik seringkali menjadi kendala bagi guru karena hampir sebagian besar peserta didik memiliki perbedaan minat, perhatian dan kebutuhan sebagaimana diungkapkan oleh salah seorang guru agama Islam yang menjelaskan bahwa kurikulum PAI merupakan hasil duplikasi dari sekolah regular. Kurikulum hanya berfungsi sebatas rambu-rambu, termasuk RPP guna memenuhi syarat dan tuntutan administrasi. RPP diimplementasikan secara kondisional, dalam arti tidak konsisten dengan perencanaan. Hal ini disebabkan adanya heterogenitas anak yang tidak memungkinkan jika RPP dan ujian didesain secara individual.

Proses pembelajaran juga telah mengikuti prinsip pembelajaran, seperti memberikan pijakan pengalaman dan pembiasaan, pujian, dan bekerja sama dengan keluarga. Namun demikian, kurangnya permainan, sikap sabar dan kasih sayang guru serta penerapan kerja kelompok dalam berbagai kegiatan pembelajaran memberikan dampak terhadap terbatasnya kemampuan sosial. Oleh karenanya, guru agama Islam yang mengajar pada peserta didik tunagrahita SD Kelas Awal hendaknya merupakan pendidik yang menjalankan tugasnya dengan panggilan jiwa dan mempertimbangkan beberapa metode variatif guna memperkaya kegiatan bermain, bernyanyi dan bercerita. Bahkan jika diperlukan, guru dapat menggunakan metode bermain peran, simulasi dan karyawisata.

\section{d. Media}

Media pembelajaran adalah alat/sarana yang digunakan dalam kegiatan pembelajaran dengan tujuan pengefektifan proses komunikasi, materi, informasi dan pesan-pesan pembelajaran. Media pembelajaran sangat penting bagi peserta didik tunagrahita dikarenakan memiliki kesulitan dalam proses berfikir sehingga dibutuhkan media yang konkret untuk memahami materi yang abstrak, membangkitkan motivasi dan menarik perhatian, memfungsikan seluruh indera, mendekatkan dunia teori dengan realita, meningkatkan terjadinya diskusi/interaksi, menyajikan informasi belajar yang dapat diulang-ulang.

Media pembelajaran diutamakan yang berupa uadio visual aids, ketersediaannya cukup dan layak pakai. Selama benda-benda asli dapat disajikan, 
maka guru hendaknya mengutamakan media asli tersebut dalam proses pembelajaran.

Pengadaan media pembelajaran seringkali terkendala oleh terbatasnya anggaran, Kementerian Agama tidak memberi bantuan baik dalam bentuk langsung maupun tidak langsung. Hal ini terbukti bahwa dalam pengadaan Laboratorium PAI, guru agama Islam lebih menggandalkan hubungan kerja sama antara orang tua dan pihak sekolah melalui infak. Pernyataan ini didukung oleh hasil wawancara dari salah seorang guru agama Islam yang menjelaskan bahwa laboratorium Agama merupakan hasil kreatifitas dua guru PAI bukan bantuan dari pemerintah karena dana diperoleh dari hasil infak dan sumbangan komite.

\section{e. Assesmen}

Assesmen merupakan kebutuhan yang sangat essensial dalam proses pembelajaran. Assesmen harus dilakukan oleh guru dalam setiap proses pembelajaran. Assesmen berfungsi sebagai alat untuk mengetahui kemajuan perkembangan peserta didik, kebutuhan, dan kesiapaan mental, Selain itu, penting bagi guru untuk memulai pembelajaran dengan bercakap-cakap, bercerita, mengemukakan pengalaman, dan sebagaimanya. Pada akhir proses pembelajaran, guru mereview kembali kegiatan pembelajaran yang telah dilakukan dengan cara menanyakan kembali apa yang telah dilakukan peserta didik.

\section{Evaluasi Hasil Pembelajaran}

Prosedur, mekanisme, cara dan alat yang digunakan dalam evaluasi peserta didik tunagrahita SD Kelas Awal ini masih sama seperti yang dilakukan pada SD umum. Namun demikian, cara dan alat perlu dimodifikasi sesuai kebutuhan dan kemampuan setiap individu, termasuk waktu dan tempat evaluasi (misal: waktu diperpanjang, tempat tertentu, alat melalui penyajian gambargambar). Selain 60\% gambar yang diperlukan berupa gambar hidup (video/film), peserta didik juga dimotivasi untuk mampu menceritakan kembali isi film secara sederhana. Adapun Tes kognitif dapat dilakukan melalui tes tertulis dengan berbagai modifikasi. Instrumen utama yang harus digunakan adalah pengamatan/observasi individual, sebab penilaian diuatamakan pada aspek afektif dan psikomotorik. Sebagai contoh: jika terdapat seorang anak yang rajin 
sholat, tetapi bacaan sholatnya kurang bagus, maka penilaiannya lebih baik dibandingkan dengan anak yang penguasaan bacaan sholatnya baik, namun enggan melakukan sholat.

Untuk ujian akhir program tidak diberlakukan ujian nasional (UN), melainkan ujian sekolah. Hal ini dikarenakan kemampuan peserta didik tunagrahita maksimal ekuivalen dengan kemampuan akademik peserta didik kelas III SD umum.

\section{Kesimpulan}

Sesuai dengan analisis kritis terhadap hasil penelitian, diperoleh beberapa temuan yang dapat disimpulkan sebagai berikut:

Pertama, perencanaan pembelajaran (kurikulum) PAI di SDLB Tunagrahita mengacu kepada kurikulum SD umum, termasuk Standar Kompetensi Lulusan dan Standar Isi, baik Standar Kompetensi maupun Kompetensi Dasar, dan telah dijabarkan ke dalam alur yang sesuai dengan sistematika pengembangan kurikulum pada umumnya. Kurikulum PAI SDLB Tunagrahita pada Kurikulum Satuan Tingkat Pendidikan (KTSP) SDLB belum dilakukan modifikasi, substitusi, ataupun omisi. Modifikasi kurikulum baru dilakukan atas inisiatif dan kreativitas guru. Pada tataran kelembagaan belum tuntas dilakukan, namun telah mulai dirintis melalui penyusunan buku pedoman. Kedua, pelaksanaan pembelajaran yang terkait dengan tujuan, materi, metode, media, dan asesmen perlu disesuaikan dengan kebutuhan dan kemampuan masing-masing anak secara individual, karena kemampuan peserta didik tidak dapat dipersamakan dan distandarisasikan. Selain itu, diperlukan guru yang responsif, khususnya responsif terhadap hak anak, sensitif, stimulatif, ekspresif, empatik, komunikatif dan konsultatif, sehingga proses pembelajaran dapat mengantarkan peserta didik untuk mengembangkan suatu pola hidup yang seimbang dan selaras, baik antara hubungan manusia dengan Allah SWT, manusia dengan sesama manusia, manusia dengan diri sendiri, serta manusia dengan alam sekitarnya. Ketiga, evaluasi hasil pembelajaran baik yang terkait dengan prosedur, mekanisme, cara dan alat yang digunakan sama seperti yang dilakukan pada SD umum. Namun telah terjadi modifikasi pada bentuk soal. Tidak diberlakukan ujian nasional (UN) melainkan ujian sekolah untuk evaluasi akhir program. 


\section{Daftar Pustaka}

Arifin, Metodik Khusus Pendidikan Agama, Jakarta, Hidakarya, 2001.

Badruzaman, Ahmad. Strategi dan Pendekatan dalam Pembelajaran. Yogyakarta, Ar Ruuz 2006.

Borich, Gary, D. Effective Teaching Methode. Thir Edition. Ohio, Merill an Imprint of Prentice Halll, 1996.

Carloz F. Diaz, Carol Marra Pelleiter dan Eugene F. Provenzo Jr., Touch the Future Teach, Boston, Pearson Education Inc., 2006.

Depdiknas, Pedoman Khusus Penyelenggaraan Pendidikan Inklusif: Pedoman Khusus Kegiatan Pembelajaran, Jakarta, Depiknas, 2006.

E Woolfolk, Anita. Educational Psycho and the Classroom Teacher. Boston, Allyn and Bacon.

Humaidi, M.K. Model-Model Pembelajaran Kreatif., Bandung, Rosdakarya, 2006.

Mansyur, Metodologi Pendidikan Agama, Jakarta, Forum, 1981.

Masitoh, dkk, Pendekatan Belajar Aktif di Taman Kanak-Kanak, Jakarta, Depdiknas, 2005.

M. Gagne, Robert, Essentials of Lerning for Instruction, Florida, Deiden Press, 1975.

Mohammad Ansyar, Kurikulum dalam Menyongsong Otonomi Pendidikan di Era Globalisasi, Peluang, Tantangan, dan Arah, dalam jurnal Pendidikan Islam TA'DIB, Maret 2002, (No. 04), ISSN 1401-6773, Fakultas Tarbiyah IAIN Raden Patah Palembnag.

NK, Roestiyah. Strategi Belajar Mengajar, Jakarta, Rineka Cipta, 1991.

Syah Muhibbin, Psikologi Pendidikan dengan Pendekatan Baru, Bandung, Remaja Rosdakarya, 2008.

S. Nasution, Berbagai Pendekatan dalam Proses Belajar dan Mengajar, Jakarta, Bina Aksara, 1984.

S. Vargas, Julie. Behavioral Psychology for Teachers. New York, Harper and Row Publishers.

Zuhairini dkk, Metodologi Pengajaran Agama Islam, Jakarta, Pustaka Firdaus, 2004. 
54 | BELAJEA : Jurnal Pendidikan Islam, Vol. 2, No. 01, 2017 